\title{
An Application of the Taguchi Method (Robust Design) to Environmental Engineering: Evaluating Advanced Oxidative Processes in Polyester-Resin Wastewater Treatment
}

\author{
Messias Borges Silva1,2*, Livia Melo Carneiro1, João Paulo Alves Silva1, \\ Ivy dos Santos Oliveira1, Hélcio José Izário Filho', Carlos Roberto de Oliveira Almeida1 \\ ${ }^{1}$ Department of Chemical Engineering, School of Engineering of Lorena EEL, São Paulo University USP, \\ Lorena, Brazil \\ ${ }^{2}$ Production Department, Universidade Estadual Paulista-Faculdade de Engenharia do campus de \\ Guaratinguetá-UNESP, Guaratinguetá, Brazil \\ Email: ${ }^{\text {messias@dequi.eel.usp.br }}$
}

Received 9 July 2014; revised 26 August 2014; accepted 9 September 2014

Copyright (C) 2014 by authors and Scientific Research Publishing Inc.

This work is licensed under the Creative Commons Attribution International License (CC BY).

http://creativecommons.org/licenses/by/4.0/

\section{(c) (i) Open Access}

\begin{abstract}
This paper presents the Taguchi Method, a statistical design modelling for experiments applied in environmental engineering. This method was applied to optimize the treatment conditions of polyester-resin effluent by means of Advanced Oxidative Processes (AOPs) using chemical oxygen demand (COD) as response parameter. The influence of each independent parameter including respective interactions was evaluated by Taguchi Method, which allowed determining the most statistically significant variables and conditions to best fit the process. Results showed that Taguchi Method is a very useful tool for environmental engineering field and possible simplifications of analysis and calculations through commercially available software.
\end{abstract}

\section{Keywords}

Taguchi Method, Statistical Optimization, Advanced Oxidative Processes, Wastewater

\footnotetext{
${ }^{*}$ Corresponding author.
} 


\section{Introduction}

Genichi Taguchi developed the foundations of robust design introduced in the 1950s and 1960s. As cited by Padke [1] the Taguchi Method may be applied to a wide variety of problems. The application of the method in electronics, automotive products, photography and many others industries had been an important factor in the rapid industrial growth of Japanese industries. The Taguchi Method is based on many ideas extracted from standard statistical design of experiments (SDOE or DOE) [2]-[4], because a conventional design optimization may not always satisfy the desired targets [5]. Furthermore, this method provides other advantages such as economical reduction and variability of the response variable; it also ensures an optimum decision during laboratory experiments or plant operations. It is an important tool to improve the productivity of the research and development activity; it reduces economically the number of trials being applied to any processes, even including environmental engineering and can be used to optimize processes.

In this paper, all steps associated to the application of the Taguchi Method will be described, as well as the tools (orthogonal arrays OA, signal-to-noise ratio $S / N$ and analysis of variance ANOVA) illustrating an application in the environmental engineering field, using advanced oxidative process (AOP) for the treatment of a wastewater from a polyester-resin factory.

Physical and chemical processes have been the most applied processes in such effluents treatments, which include air stripping at different $\mathrm{pH}$ values, powdered activated carbon (PAC), adsorption, filtration and EDTA chelation. Respirometry was used for toxicity reduction evaluation after physical and chemical effluent fractionation. From all procedures investigated, only air stripping was significantly effective in reducing wastewater toxicity. Air stripping in $\mathrm{pH} 7$ reduced toxicity in $18.2 \%$, while in $\mathrm{pH} 11$ a toxicity reduction of $62.5 \%$ was observed [6].

The removal of diethyleneglycol (DEG) and several polyether-polyols of different molecular weights by ultrafiltration were studied. These polyether-polyols consist of polyethyleneglycols (PEG) of different molecular weights (800 and 6000) and two ethylene oxide-propylene oxide copolymers: Pluronic PE6100 and Alcupol F4811. No significant retention was obtained for DEG and PEG-800, but for PEG-6000, rejection coefficients higher than $80 \%$ were reached. Temperature effects, transmembrane pressure and feed rate on both permeate flux and rejection coefficient were also studied. Secondly, the same procedure was followed by $0.1 \% \mathrm{w} / \mathrm{w}$ solutions of Alcupol and Pluronic, obtaining rejection coefficients of almost 100\% [7].

Advanced Oxidative Process (AOP) is an important alternative for treatment of contaminated water and wastewater containing hardly-biodegradable anthropogenic substances, pharmaceuticals, pesticides, disinfections of drinking waters [8]-[15] and used after well-established methods (flocculation, precipitation, adsorption, etc.) and before biological methods (aerobic activated sludge) to enhance the biodegradability of wastewater. AOPs modify the pollutants structure producing less toxic and biodegradable products, which can be treated by a biological process. AOPs can be defined as methods where hydroxyl radicals $(\mathrm{HO} \bullet$ ) are produced in sufficient quantities to act as main oxidizing agent. Hydroxyl radicals can be generated as a result of the combination of strong oxidizing agents, such as hydrogen peroxide and ozone. Ultraviolet (UV) or visible radiation and catalysts such as metal ions and semiconductors can also be used to create hydroxyl radicals [16] [17]. AOPs using the combination of ozone with other oxidant agents (UV radiation and hydrogen peroxide) allow only oxidation of dissolved organic compounds that are normally refractory to the direct attack of ozone. UV radiation and hydrogen peroxide addition lead to the ozone demolition and hydroxyl radical formation [18].

There are many types of AOPs applied for the oxidation of pollutants in water and wastewater, as catalytic ozonation $\left(\mathrm{O}_{3}\right)$ [19] [20], or combination of hydrogen peroxide with ozone $\left(\mathrm{H}_{2} \mathrm{O}_{2} / \mathrm{O}_{3}\right)$ or ultra violet $\left(\mathrm{H}_{2} \mathrm{O}_{2} / \mathrm{UV}\right)$, and UV/titanium dioxide [21] or UV/zinc oxide [22], treating pollutants by oxidation and by hydroxyl radical [23]. Despite AOPs have been widely studied to reduce toxicity of various types of industrial effluents, the use of AOPs in the treatment of effluents from polyester resins facture has been little used.

In this context, the present study aims to apply the Taguchi Method to evaluate advanced oxidative process for the treatment of a recalcitrant effluent from polyester-resin facture.

\section{Materials and Methods}

\subsection{Steps of the Taguchi Method}

The following steps for implementing Taguchi experimental design according to Barrado et al. [24] are:

1) Select the output variable to be optimized, 2) identify factors (input variables) affecting output variable (re- 
sponse) and choose levels to be tested, 3) select orthogonal array, 4) assign factors and interactions to the columns of the array, 5) perform experiments, 6) carry out a statistical analysis and the signal-to-noise ratio and determine the optimal conditions to adjust factor levels and 7) perform confirmatory experiment, if necessary.

\subsubsection{Planning the Experiment}

In this stage, the researcher must define or choose the factors (independent variables or input variables) and the respective operation levels. After this choice, it is necessary to find out the best or economical matrix experiment (orthogonal array OA), which can be obtained in the literature [1] [25]. Then, choose the desired signalto-noise ratio function (smaller-the-better, larger-the-better, nominal-the-better), equation 1, equation 2 and equation 3 , respectively.

\subsubsection{Signal-to-Ratio $\mathrm{S} / \mathrm{N}$}

The signal-to-noise ratio is a logarithmic function used to optimize the process or product design, minimizing the variability. The signal-to-noise ratio can also be understood as an inverse of variance and maximization of signal-to noise ratio allowing reduction of the variability of the process against undesirable changes in neighbor environment (also named uncontrollable factor or factor of noise). To minimize variability, we must choose the level of factor that produces the maximum value of $S / N$.

Three types of common problems and respective signal-to-ratio function are presented as follows:

Smaller-the better

$$
S / N=-10 \log \left[\frac{1}{n} \sum_{i=1}^{n} y_{i}^{2}\right]
$$

where $y_{i}$ denote the n observations of response variable

Larger-the-better

$$
S / N=-10 \log \left[\frac{1}{n} \sum_{i=1}^{n} \frac{1}{y_{i}^{2}}\right]
$$

Nominal-the-better

$$
S / N=10 \log \frac{\mu^{2}}{\sigma^{2}}
$$

where $\mu_{i}^{2}$ denotes the square of mean and $\sigma^{2}$ the variance of the observations of the replicated response values.

Here it is important to emphasize the needs of randomizing the trials to minimize systematic error. To illustrate this paper, a wastewater obtained from a polyester-resin factory was used and the following factors were defined as presented in Table 1. An orthogonal array $\mathrm{L}_{16}$ was used which means 16-trial experimental matrix, presented in Table 2 . The orthogonal array $\mathrm{L}_{16}$ was chosen by using the degree of freedom method as cited by Padke [1].

\subsubsection{Orthogonal Array $\mathrm{OA}$ and Linear Graphs}

Orthogonal array is a special experimental matrix designed by $\mathrm{L}_{\mathrm{i}}$, where $\mathrm{i}$ is the number of trials of experimental matrix or total degree of freedom and consists of a set of experiments where we change the settings of process parameters. The use of OA allows the effects of several process parameters to be determined efficiently, Padke [1]. Here, orthogonality is interpreted in the combinatory sense; that is, for any pair of columns, all combinations of factor levels occur and they occur at an equal number of times. This is called balancing property and it implies orthogonality. Each column of AO has associated one degree of freedom (number of levels minus one) and can be assigned one factor or interaction. A list of orthogonal arrays and linear graphs can be obtained in Padke [1] and Taguchi and Konishi [25].

\subsubsection{Linear Graphs}

To enhance the flexibility of arrays, Dr. Taguchi used linear graphs to represent the arrays. By using these graphs and triangular tables provided by Taguchi, the experimenter can effectively study interactions between 
Table 1. Factors and levels evaluated in Taguchi $\mathrm{L}_{16}$ Orthogonal Array.

\begin{tabular}{cccc}
\hline & Factor & Level 1 & Level 2 \\
\hline A & $\mathrm{pH}$ & 3 & 5 \\
B & Temperature $\left({ }^{\circ} \mathrm{C}\right)$ & 25 & 35 \\
$\mathrm{C}$ & $\mathrm{Fe}^{2+}$ Concentration $\left(\mathrm{g} \cdot \mathrm{l}^{-1}\right)$ & 0.6 & 1.2 \\
$\mathrm{D}$ & $\mathrm{H}_{2} \mathrm{O}_{2}$ Concentration $\left(\mathrm{g} \cdot \mathrm{l}^{-1}\right)$ & 14 & 28 \\
$\mathrm{E}$ & Ozone Flow Rate $\left(\mathrm{g} \cdot \mathrm{h}^{-1}\right)$ & 0.10 & 0.21 \\
$\mathrm{~F}$ & Stirring $(\mathrm{rpm})$ & 70 & 150 \\
$\mathrm{G}$ & UV radiation & Absent & present \\
\hline
\end{tabular}

Table 2. Taguchi $\mathrm{L}_{16}$ Orthogonal Array and response variables.

\begin{tabular}{|c|c|c|c|c|c|c|c|c|c|c|c|c|c|c|c|}
\hline & A1 & C2 & AxC3 & D4 & AxD5 & CxD6 & ExG7 & E8 & AxE9 & F10 & H11 & B12 & AxB13 & AxG14 & G15 \\
\hline & $\mathrm{pH}$ & $\mathrm{Fe}$ & $\mathrm{pH} / \mathrm{Fe}$ & $\mathrm{H}_{2} \mathrm{O}_{2}$ & $\mathrm{pH} / \mathrm{H}_{2} \mathrm{O}_{2}$ & $\mathrm{H}_{2} \mathrm{O}_{2} / \mathrm{Fe}$ & $\mathrm{O}_{3} / \mathrm{UV}$ & $\mathrm{O}_{3}$ & $\mathrm{pH} / \mathrm{O}_{3}$ & Stir & $\mathrm{pH} /$ Stir & $\mathrm{T}$ & $\mathrm{pH} / \mathrm{T}$ & $\mathrm{pH} / \mathrm{UV}$ & UV \\
\hline 1 & 1 & 1 & 1 & 1 & 1 & 1 & 1 & 1 & 1 & 1 & 1 & 1 & 1 & 1 & 1 \\
\hline 2 & 1 & 1 & 1 & 1 & 1 & 1 & 1 & 2 & 2 & 2 & 2 & 2 & 2 & 2 & 2 \\
\hline 3 & 1 & 1 & 1 & 2 & 2 & 2 & 2 & 1 & 1 & 1 & 1 & 2 & 2 & 2 & 2 \\
\hline 4 & 1 & 1 & 1 & 2 & 2 & 2 & 2 & 2 & 2 & 2 & 2 & 1 & 1 & 1 & 1 \\
\hline 5 & 1 & 2 & 2 & 1 & 1 & 2 & 2 & 1 & 1 & 2 & 2 & 1 & 1 & 2 & 2 \\
\hline 6 & 1 & 2 & 2 & 1 & 1 & 2 & 2 & 2 & 2 & 1 & 1 & 2 & 2 & 1 & 1 \\
\hline 7 & 1 & 2 & 2 & 2 & 2 & 1 & 1 & 1 & 1 & 2 & 2 & 2 & 2 & 1 & 1 \\
\hline 8 & 1 & 2 & 2 & 2 & 2 & 1 & 1 & 2 & 2 & 1 & 1 & 1 & 1 & 2 & 2 \\
\hline 9 & 2 & 1 & 2 & 1 & 2 & 1 & 2 & 1 & 2 & 1 & 2 & 1 & 2 & 1 & 2 \\
\hline 10 & 2 & 1 & 2 & 1 & 2 & 1 & 2 & 2 & 1 & 2 & 1 & 2 & 1 & 2 & 1 \\
\hline 11 & 2 & 1 & 2 & 2 & 1 & 2 & 1 & 1 & 2 & 1 & 2 & 2 & 1 & 2 & 1 \\
\hline 12 & 2 & 1 & 2 & 2 & 1 & 2 & 1 & 2 & 1 & 2 & 1 & 1 & 2 & 1 & 2 \\
\hline 13 & 2 & 2 & 1 & 1 & 2 & 2 & 1 & 1 & 2 & 2 & 1 & 1 & 2 & 2 & 1 \\
\hline 14 & 2 & 2 & 1 & 1 & 2 & 2 & 1 & 2 & 1 & 1 & 2 & 2 & 1 & 1 & 2 \\
\hline 15 & 2 & 2 & 1 & 2 & 1 & 1 & 2 & 1 & 2 & 2 & 1 & 2 & 1 & 1 & 2 \\
\hline 16 & 2 & 2 & 1 & 2 & 1 & 1 & 2 & 2 & 1 & 1 & 2 & 1 & 2 & 2 & 1 \\
\hline
\end{tabular}

experimental factors as well as effects of individual factors (main effects) themselves. Linear graphs make this possible by providing a logical scheme for assigning interactions to the orthogonal array without confounding effects of interactions with effects of the studied individual factors. In this paper, a linear graph Taguchi $\mathrm{L}_{16}$ (Figure 1) was used, which presents an arrangement with seven factors (points 1, 2, 4, 8, 10, 12 and 15) and eight interactions (lines 3, 5, 6, 7, 9, 11, 13 and 14). Factors distribution in the linear graph is made in order to obtain interactions that might prove to be more significant [1].

\subsubsection{Performing the Experiment}

By this time, the researcher must conduct the matrix experiment to obtain values of the response variable and the signal-to-noise ratio. After conducting the matrix experiment, the results fill the Table 2 and proceed the calculus of signal-to-noise ratio. Here, we reinforce the need to randomize the trials.

\subsubsection{Analyzing the Experimental Results}

In this step the researchers fulfill Table 2 and perform the calculus of the effects of factors, signal-to-noise ratio and ANOVA. 


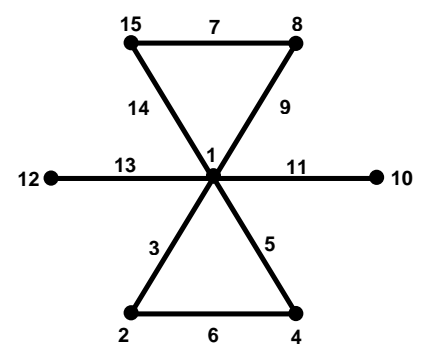

Figure 1. Linear graph Taguchi $\mathrm{L}_{16}$.

\subsubsection{Calculus of Effects}

Main effects of a factor level is defined as the deviation caused from the overall mean. Using our illustration to evaluate the effect of factor $A$, shown in Table 2, the mean under condition $A_{1}$ assigned by $m_{A 1}$ and the mean under condition $\mathrm{A}_{2}$ assigned by $\mathrm{m}_{\mathrm{A} 2}$ can be calculated by:

$$
m_{\mathrm{A} 1}=\frac{1}{8}(R 1+R 2+R 3+R 4+R 5+R 6+R 7+R 8)
$$

where $\mathrm{Ri}$ is the mean value of response at trial $\mathrm{i}$.

The effect can be interpreted as the mean of responses when factor is set on a specified level.

$$
m_{A 2}=\frac{1}{8}(R 9+R 10+R 11+R 12+R 13+R 14+R 15+R 16)
$$

The effects of every other factor are equally calculated.

\subsubsection{Analysis of Variance (ANOVA)}

ANOVA is used to find out main and interaction effects of categorical independent variables (called "factors") on an interval dependent variable. In that context, ANOVA is used to judge how strong the influence of the factors over the response variable is or how different factors affect the response variable to a different degree. About ANOVA there are many introductory texts on elementary statistical theory books.

\subsection{Apparatus and Chemicals}

The basic aim of this work is to treat a wastewater from polyester and alkyl resin manufacturing industry using the Taguchi Method. The wastewater is a mixture of various organic raw materials unreacted (vegetable oils, abietic acid, benzoic acid, phtalic anidride, hexahydrophtalic anidride, butyl phenol, neopentyl glycol, xylol, toluol, isophtalic acid, terephtalic acid, maleic anidride, penthaerithritol) and polyester. The manufacturing process generates a wastewater with a COD content of over 220,000 mg. $\mathrm{l}^{-1}$. Chemical Oxygen Demand (COD) analysis was carried out by a FEMTO-600 spectrophotometer using dichromate solution as the oxidant in strong acid medium. Color is developed during the oxidation and measured against a water blank using a colorimeter. The change of the dichromate solution color was determined at $\lambda=620 \mathrm{~nm}$.

Polyester-resin effluent was submitted to different treatments conditions by homogeneous AOPs. The treatments were conducted in a glass reactor with a capacity of $400 \mathrm{ml}$, equipped with a water-cooled system and a magnetic stirring, as shown in Figure 2. Ultraviolet radiation was provided by a medium-pressure mercury vapor lamp (125 W Phillips) placed in the solution through a quartz bulb [26] [27]. A GEHAKA pH meter was used for $\mathrm{pH}$ measurement. Ozone was bubbled through the solution using a dielectric barrier discharge Ozonator. Air was bubbled through the solution using a conventional compressor. A magnetic stirrer was used throughout the experiment to ensure a homogeneous medium. Fenton reagent (mixture of $\mathrm{H}_{2} \mathrm{O}_{2}$ and $\mathrm{Fe}^{2+}$ cation) was prepared using $\mathrm{H}_{2} \mathrm{O}_{2} 30 \% \mathrm{v} / \mathrm{v}$ and $\mathrm{FeSO}_{4} 0.18 \mathrm{~mol} \cdot \mathrm{l}^{-1}$.

The percent reduction of COD was conducted by applying a Taguchi experimental design [24] [28]. The choice of factors and their levels (Table 1) were made after brainstorming with people who work on environmental management field. The level of factors was adjusted according to the respective assays (Table 2) to perform the AOPs treatment. After the cell reactor was fulfilled, the electric stirrer, temperature probe, $\mathrm{pH}$ electrode, ozone-feeding and air-feeding glass tube were connected and UV generator turned on. The $\mathrm{pH}$ was adjusted by 


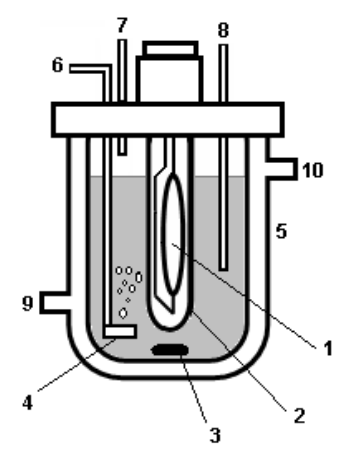

Figure 2. Schematic representation of the conventional photochemical reactor (1-mercury vapor lamp; 2-quartz bulb; 3magnetic bar; 4- $\mathrm{O}_{3}$ disperser; 5-cooling jacket; 6-inlet $\mathrm{O}_{3}$; 7-gas outlet; 8-sample removal.

using hydrochloric acid or sodium hydroxide solutions.

\section{Results and Discussion}

Aiming to evaluate the potential application of AOPs in reducing the toxicity of polyester resin effluent, assays were conducted to study the influence of Fe (II) concentration, hydrogen peroxide concentration, ozone concentration, UV radiation, $\mathrm{pH}$, temperature and stirring. Chemical Oxygen Demand (COD) was selected as the response variable to be optimized (minimized). To avoid a multivariate analysis and use a minimum set of experiments one Taguchi $\mathrm{L}_{16}$ Orthogonal Array was chosen. Taguchi $\mathrm{L}_{16}$ design orthogonal array permits to find the effects of each individual controllable factor on the response (\% of COD reduction), which are presented in Table 3.

- Experimental condition in which we observed largest reduction of COD (33.3\%) of the treated effluent was the assay 15 (Table 3), in which the concentration of $\mathrm{Fe}^{2+}$ and $\mathrm{H}_{2} \mathrm{O}_{2}\left(1.2 \mathrm{~g} \cdot \mathrm{l}^{-1}\right.$ and $28 \mathrm{~g} \cdot \mathrm{l}^{-1}$, respectively) were the highest level, indicating a possible positive effect of higher concentrations of these variables on the reduction of COD. It is important to note that the assay was carried out in presence of UV radiation and absence of ozone, and at $\mathrm{pH}$ 5. A similar reduction of COD (33\%) was observed in assay 8, where experimental conditions are similar to those of assay 15, except for the $\mathrm{pH}$ conditions and ozone.

- Assays performed under the presence of UV radiation, COD reduction was above 20\%, except for assay 9, which showed 13\% COD reduction, even in the presence of UV radiation. However, in this experiment the most relevant parameters were at level 1 , which corresponds to minimum concentrations of hydrogen peroxide and $\mathrm{Fe}^{2+}$ concentration, and $\mathrm{pH}$ 5. Results of COD reduction showed that assays performed in the absence of UV radiation reached COD reduction of about $12 \%$, which means half of the mean value of COD reduction obtained for assays performed in the presence of UV radiation. This result suggests a major importance of the UV radiation presence on the polyester resin effluent degradation.

- In general, the largest reductions of COD were obtained when the $\mathrm{H}_{2} \mathrm{O}_{2}$ concentration factor was at the highest level and in the presence of UV radiation, in assays 3, 8, 12 and 15. The greatest COD reductions were observed in assays 8 and 15 (33\% and 34\%, respectively), which were carried out at $\mathrm{Fe}^{2+}$ concentration at its highest level, even in different conditions of $\mathrm{pH}$ and ozone concentration. $\mathrm{Ph}$ is a significant parameter on the pollutant AOPs degradation, for example, in Fenton and photo-Fenton processes, many studies have reported $\mathrm{pH}$ values around three [16]. Generally, at $\mathrm{pH}$ values above four, a decrease on hydrogen peroxide decomposition rate occurs due $\mathrm{Fe}^{2+}$ species precipitation as iron hydroxide [16]. However, in this study $\mathrm{pH}$ presented a low effect on the degradation process within the $\mathrm{pH}$ range studied.

\subsection{Statistical Analysis}

The statistical significance of main effects and interactions on the reduction in COD for the polyester resin effluent treatment was confirmed by analysis of variance effects (ANOVA) (Table 4). Statistical significance of the factors effects was considered at a 95\% confidence level and it is related by p-value in the ANOVA. Ac- 
Table 3. Taguchi $\mathrm{L}_{16}$ Orthogonal Array and results obtained in the detoxification treatment by Advanced Oxidative Processes.

\begin{tabular}{|c|c|c|c|c|c|c|c|c|c|c|c|c|c|c|c|c|c|}
\hline \multirow[b]{2}{*}{ Assays } & A1 & C2 & AC3 & D4 & AD5 & CD6 & EG7 & E8 & AE9 & F10 & AF11 & B12 & AB13 & AG14 & G15 & \multirow{2}{*}{$\begin{array}{c}\text { COD } \\
\text { Reduction }\end{array}$} & \multirow[b]{2}{*}{ SD } \\
\hline & $\mathrm{pH}$ & $\begin{array}{l}\mathrm{Fe}^{2+} \\
\left(\mathrm{g} \cdot \mathrm{l}^{-1}\right)\end{array}$ & $\begin{array}{l}\mathrm{pH} / \\
\mathrm{Fe}^{2+}\end{array}$ & $\begin{array}{l}\mathrm{H}_{2} \mathrm{O}_{2} \\
\left(\mathrm{~g} \cdot \mathrm{l}^{-1}\right)\end{array}$ & $\begin{array}{c}\mathrm{pH} / \\
\mathrm{H}_{2} \mathrm{O}_{2}\end{array}$ & $\begin{array}{l}\mathrm{H}_{2} \mathrm{O} / \\
\mathrm{Fe}^{2+}\end{array}$ & $\begin{array}{l}\mathrm{O}_{3} / \\
\mathrm{UV}\end{array}$ & $\begin{array}{c}\mathrm{O}_{3} \\
\left(\mathrm{~g} \cdot \mathrm{h}^{-1}\right)\end{array}$ & $\mathrm{pH} / \mathrm{O}_{3}$ & Stirring & $\begin{array}{c}\mathrm{pH} / \\
\text { Stirring }\end{array}$ & Temp & $\begin{array}{l}\mathrm{pH} / \\
\text { Temp }\end{array}$ & $\begin{array}{l}\mathrm{pH} / \\
\mathrm{UV}\end{array}$ & UV & & \\
\hline 1 & 3 & 0.6 & 1 & 14 & 1 & 1 & 1 & 0.10 & 1 & 70 & 1 & 25 & 1 & 1 & absent & 6.34 & 0.11 \\
\hline 2 & 3 & 0.6 & 1 & 14 & 1 & 1 & 1 & 0.21 & 2 & 150 & 2 & 35 & 2 & 2 & present & 24.36 & 0.26 \\
\hline 3 & 3 & 0.6 & 1 & 28 & 2 & 2 & 2 & 0.10 & 1 & 70 & 1 & 35 & 2 & 2 & present & 27.99 & 0.27 \\
\hline 4 & 3 & 0.6 & 1 & 28 & 2 & 2 & 2 & 0.21 & 2 & 150 & 2 & 25 & 1 & 1 & absent & 12.16 & 2.79 \\
\hline 5 & 3 & 1.2 & 2 & 14 & 1 & 2 & 2 & 0.10 & 1 & 150 & 2 & 25 & 1 & 2 & present & 19.52 & 0.62 \\
\hline 6 & 3 & 1.2 & 2 & 14 & 1 & 2 & 2 & 0.21 & 2 & 70 & 1 & 35 & 2 & 1 & absent & 18.10 & 0.98 \\
\hline 7 & 3 & 1.2 & 2 & 28 & 2 & 1 & 1 & 0.10 & 1 & 150 & 2 & 35 & 2 & 1 & absent & 17.13 & 0.26 \\
\hline 8 & 3 & 1.2 & 2 & 28 & 2 & 1 & 1 & 0.21 & 2 & 70 & 1 & 25 & 1 & 2 & present & 33.30 & 0.70 \\
\hline 9 & 5 & 0.6 & 2 & 14 & 2 & 1 & 2 & 0.10 & 2 & 70 & 2 & 25 & 2 & 1 & present & 12.97 & 0.96 \\
\hline 10 & 5 & 0.6 & 2 & 14 & 2 & 1 & 2 & 0.21 & 1 & 150 & 1 & 35 & 1 & 2 & absent & 7.49 & 0.34 \\
\hline 11 & 5 & 0.6 & 2 & 28 & 1 & 2 & 1 & 0.10 & 2 & 70 & 2 & 35 & 1 & 2 & absent & 10.28 & 2.88 \\
\hline 12 & 5 & 0.6 & 2 & 28 & 1 & 2 & 1 & 0.21 & 1 & 150 & 1 & 25 & 2 & 1 & present & 23.95 & 2.16 \\
\hline 13 & 5 & 1.2 & 1 & 14 & 2 & 2 & 1 & 0.10 & 2 & 150 & 1 & 25 & 2 & 2 & absent & 10.46 & 0.09 \\
\hline 14 & 5 & 1.2 & 1 & 14 & 2 & 2 & 1 & 0.21 & 1 & 70 & 2 & 35 & 1 & 1 & present & 24.40 & 4.97 \\
\hline 15 & 5 & 1.2 & 1 & 28 & 1 & 1 & 2 & 0.10 & 2 & 150 & 1 & 35 & 1 & 1 & present & 34.09 & 0.83 \\
\hline 16 & 5 & 1.2 & 1 & 28 & 1 & 1 & 2 & 0.21 & 1 & 70 & 2 & 25 & 2 & 2 & absent & 16.39 & 2.68 \\
\hline
\end{tabular}

$\mathrm{SD}=$ standard deviation; $\mathrm{COD}=$ chemical oxygen demand.

Table 4. Analysis of variance for the response evaluated in the experimental design.

\begin{tabular}{|c|c|c|c|c|c|c|c|}
\hline Variation source & Sum of squares & DF & Mean sum of squares & $\mathbf{F}$ & $\mathbf{p}$ & & Contribution (\%) \\
\hline $\mathrm{pH}$ & 13.3416 & 1 & 13.3416 & 6.1950 & 0.024205 & * & 2.1 \\
\hline $\mathrm{Fe}^{2+}$ & 94.6594 & 1 & 94.6594 & 43.9539 & 0.000006 & $*$ & 15.0 \\
\hline $\mathrm{pH} / \mathrm{Fe}^{2+}$ & 1.7633 & 1 & 1.7633 & 0.8188 & 0.378960 & & 0.3 \\
\hline $\mathrm{H}_{2} \mathrm{O}_{2}$ & 80.6292 & 1 & 80.6292 & 37.4392 & 0.000015 & * & 12.8 \\
\hline $\mathrm{pH} / \mathrm{H}_{2} \mathrm{O}_{2}$ & 1.7887 & 1 & 1.7887 & 0.8306 & 0.375632 & & 0.3 \\
\hline $\mathrm{H}_{2} \mathrm{O}_{2} / \mathrm{Fe}^{2+}$ & 1.3661 & 1 & 1.3661 & 0.6343 & 0.437435 & & 0.2 \\
\hline $\mathrm{O}_{3} / \mathrm{UV}$ & 0.3172 & 1 & 0.3172 & 0.1473 & 0.706190 & & 0.1 \\
\hline $\mathrm{O}_{3}$ & 20.8645 & 1 & 20.8645 & 9.6882 & 0.006701 & $*$ & 3.3 \\
\hline $\mathrm{pH} / \mathrm{O}_{3}$ & 4.0830 & 1 & 4.0830 & 1.8959 & 0.187498 & & 0.6 \\
\hline Stirring & 0.2190 & 1 & 0.2190 & 0.1017 & 0.753909 & & 0.0 \\
\hline pH/Stirring & 1.2061 & 1 & 1.2061 & 0.5600 & 0.465111 & & 0.2 \\
\hline Temperature & 24.3201 & 1 & 24.3201 & 11.2927 & 0.003979 & * & 3.9 \\
\hline pH/Temperature & 16.5279 & 1 & 16.5279 & 7.6745 & 0.013652 & & 2.6 \\
\hline $\mathrm{pH} / \mathrm{UV}$ & 0.0286 & 1 & 0.0286 & 0.0133 & 0.909634 & & 0.0 \\
\hline UV & 333.7682 & 1 & 333.7682 & 154.9811 & 0.000000 & * & 53.0 \\
\hline Residue & 34.4577 & 16 & 2.1536 & & & & \\
\hline Total & 629.3408 & 31 & & & & & $\mathrm{R}^{2}=94.5$ \\
\hline
\end{tabular}

$\mathrm{DF}=$ degree of freedom

cording to ANOVA (design $\mathrm{L}_{16}$ ), significant variables for polyester resin effluent treatment were $\mathrm{Fe}^{2+}$ concentration, hydrogen peroxide and ozone concentration, and $\mathrm{pH}$, temperature and UV radiation. Among these variables, $\mathrm{Fe}^{2+}$ and $\mathrm{H}_{2} \mathrm{O}_{2}$ concentration, and UV radiation were considered significant with a confidence level of $99 \%$. The significant variable was responsible for $15,12.8$ and $53 \%$ for $\mathrm{Fe}^{2+}$ concentration, $\mathrm{H}_{2} \mathrm{O}_{2}$ concentration and UV 
radiation, respectively, of all the observed variation (Table 4). The analysis of variance indicates that, in the experimental evaluated range, photo-Fenton (utilization of $\mathrm{Fe}^{2+}$ and $\mathrm{H}_{2} \mathrm{O}_{2}$ in the presence of UV radiation) was the most effective method for the polyester-resin effluent treatment.

The signal-to-noise $(S / N)$ ratio concept was used to evaluate the variability and how it changes around the mean, by influence of external uncontrollable factor (noises). In this work, the goal is to reduce COD, e.g, smaller COD is better. In that condition the response is optimized and the process will be robust against external environment or uncontrollable factors [1]. As an optimized parameter COD is a smaller-is-better, the calculation of $S / N$ was made using the Equation (1). Note that $L_{16}$ orthogonal array needs 16 assays for 6 factors operating at 2 levels. That experimental matrix allows studying many factors, saving costs and time if compared with traditional full factorial design or conventional experiment in which one factor has the level changed while the other factors keep constant.

In signal-to-noise graph (Figure 3), it may be observed the effects of the variables (A-pH; B-Temperature; C-Fe ${ }^{2+}$; D- $\mathrm{H}_{2} \mathrm{O}_{2}$; E-O $\mathrm{O}_{3}$; F-Stirring; G-UV) and its interactions (AC; AD; CD; EG; AE; AF; AB; AG) studied in Taguchi $\mathrm{L}_{16}$ Orthogonal Array on the response COD reduction. Similar to the analysis of variance the signal-tonoise analysis showed that the significant factors were $\mathrm{Fe}^{2+}$ and $\mathrm{H}_{2} \mathrm{O}_{2}$ concentration, and UV radiation, and all of others variables had a greater effect when set at the highest level. Through the signal-to-noise ratio graph it was observed that the ozone and temperature factors were better for the treatment process when used on its highest level.

Therefore, based on the most significant factors (concentration of $\mathrm{H}_{2} \mathrm{O}_{2}$ and $\mathrm{Fe}^{2+}$, and $\mathrm{UV}$ radiation), we can conclude that the most appropriate treatment for polyester resin effluent is the photo-Fenton process. $\mathrm{pH}$, ozone, temperature and agitation factors, although they are not significant at statistical analysis, they are important factors which should be kept at the level of best fit $\left(\mathrm{pH} 3\right.$, ozone flow rate of $0.21 \mathrm{~g} \cdot \mathrm{h}^{-1}$, temperature of $35^{\circ} \mathrm{C}$ and agitation of $150 \mathrm{rpm})$.

\subsection{Simplification of Calculus and Analysis}

All steps of the Taguchi Methods can be simplified by using a statistical software. Nowadays, there are several types of commercial software with Taguchi's options. These are the most recommendable: MINITAB, STATISTICA, STATGRAPHICS, DESIGN EXPERT, QUALITEK and others. In this work, the STATISTICA 6.0 software was used.

\section{Conclusions}

The Taguchi Method can facilitate and optimize the work of experimenters. This method is an important means

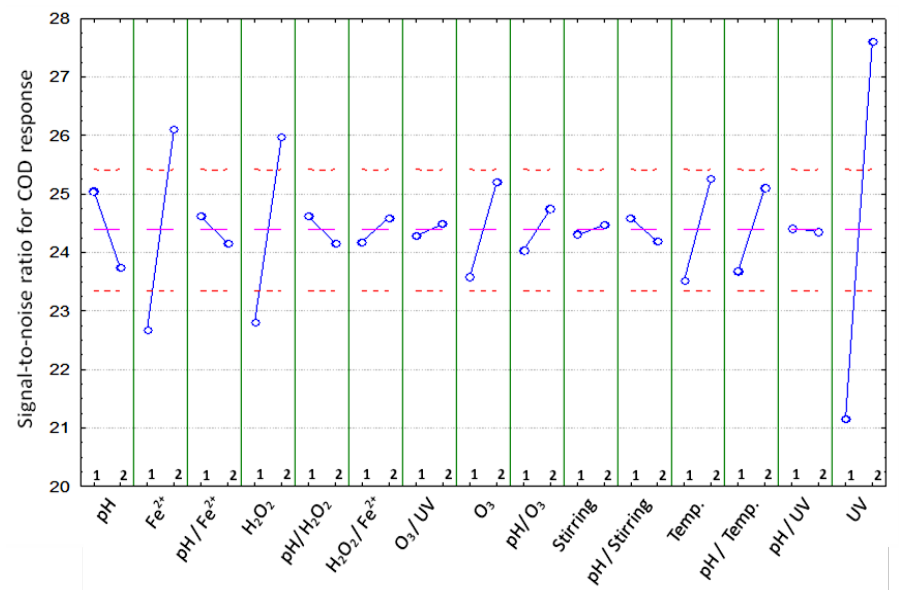

Figure 3. Effects of the factors (A-pH; B-Temperature; C-Fe ${ }^{2+} ; \mathrm{D}-\mathrm{H}_{2} \mathrm{O}_{2}$; E-O $\mathrm{O}_{3}$; F-Stirring; G-UV) and its interactions (AC; AD; CD; EG; AE; AF; $A B ; A G)$ evaluated in Taguchi $\mathrm{L}_{16}$ Orthogonal Array for COD reduction of the polyester-resin treated by Advanced Oxidative Processes. Level 1: lower; level 2: higher. 
of addressing several variables simultaneously (multivariate analysis), with fewer trials, lower costs, and a shortened duration.

Initial concentrations of $\mathrm{Fe}^{2+}$, hydrogen peroxide and ultraviolet radiation were statistically revealed to be the most susceptible to influence utilizing the Taguchi Method. The photo-Fenton process was the most effective in reducing the COD of polyester-resin effluent. Other factors that had less influence within the range of variation studied ( $\mathrm{pH}$, temperature, agitation, and ozone concentration), should result in a maintained best-fit level as defined in the Taguchi experimental design.

The treatment by means of advanced oxidative process provided an approximate $35 \%$ reduction in chemical oxygen demand of the polyester-industry wastewater. However, when compared to studies describing the treatment of this effluent by Advanced Oxidative Processes, we see that the results were relevant. This demonstrates that the Taguchi Method is a very useful tool for applications in the fields of environmental engineering and industrial wastewater treatment.

\section{Acknowledgements}

The authors gratefully acknowledge financial support from Coordenação de Aperfeiçoamento de Pessoal de Nível Superior (CAPES), and Conselho Nacional de Desenvolvimento Científico e tecnológico (CNPq)-BRAZIL.

\section{References}

[1] Padke, M.S. (1989) Quality Engineering Using Robust Design. Prentice Hall, Englewood Cliffs.

[2] Dawson, E.A. and Barnes, P.A. (1992) A New Approach to the Statistical Optimization of Catalyst Preparation. Applied Catalysis A: General, 90, 217-231. http://dx.doi.org/10.1016/0926-860X(92)85060-O

[3] Robin, A., Alves de Souza, K., Rosa, J.L. and Silva, M.B. (2002) Electrodeposition of Copper as a Route for Tantalum Drawing. Surface Engineering, 18, 120-125.

[4] Rosa, J.L., Robina, A., Silva, M.B., Baldana, C.A. and Peres, M.P. (2008) Electrodeposition of Copper on Titanium Wires: Taguchi Experimental Design Approach. Journal of Materials Processing Technology, 209, 1181-1188. http://dx.doi.org/10.1016/j.jmatprotec.2008.03.021

[5] Zang, C., Friswell, M.I. and Mottershead, J.E. (2005) A Review of Robust Optimal Design and Its Application in Dynamics. Computers \& Structures, 83, 315-326. http://dx.doi.org/10.1016/j.compstruc.2004.10.007

[6] Caffaro-Filho, R.A., Morita, D.M., Wagner, R. and Durrant, L.R. (2009) Toxicity-Directed Approach of Polyester Manufacturing Industry Wastewater Provides Useful Information for Conducting Treatability Studies. Journal of Hazards Material, 163, 92-97. http://dx.doi.org/10.1016/j.jhazmat.2008.06.063

[7] Cañizares, P., Pérez, A., Camarillo, R. and Llanos, J. (2007) Removal of Polyether-Polyols by Means of Ultrafiltration. Desalination, 206, 594-601. http://dx.doi.org/10.1016/j.desal.2006.03.582

[8] Oguz, E., Keskinler, B., Çelik, C. and Çelik, Z. (2006) Determination of the Optimum Conditions in the Removal of Bomaplex Red CR-L Dye from the Textile Wastewater Using $\mathrm{O}_{3}, \mathrm{H}_{2} \mathrm{O}_{2}, \mathrm{HCO}_{3}{ }^{-}$and PAC. Journal of Hazardous Materials, 131, 66-72.

[9] Meriç, S., Kabdalia, I., Tunay, O. and Orhon, D. (1999) Treatability of Strong Wastewaters from Polyesters Manufacturing Industry. Water Science and Technology, 39, 1-7. http://dx.doi.org/10.1016/S0273-1223(99)00247-4

[10] Parra, S.P.C. (2001) Coupling of Photocatalytic and Biological Process as a Contribution to the Detoxification of Water: Catalytic and Technological Aspects. Ph.D. Thesis, Ècole Polytechnique Fédérale de Lausanne.

[11] Legrini, O., Oliveros, E. and Braun, A.M. (1993) Photochemical Process for Water-Treatment. Chemical Reviews, 93, 671-698. http://dx.doi.org/10.1021/cr00018a003

[12] Gunten, U., Huber, M.M., Canonica, S. and Park, G.Y. (2003) Oxidations of Farmaceuticals during Ozonation an Advanced Oxidation Processes. Environmental Science \& Technology, 37, 1016-1024. http://dx.doi.org/10.1021/es025896h

[13] Chiron, S., Alba, A.F., Rodrigues, A. and Calvo, E.G. (2000) Pesticide Chemical Oxidation: State-of-the-Art. Water Resource, 2, 366-377.

[14] Silva, M.B., Almeida, C.R.O., Chaves, F.J.M., Izário Filho, H.J. and Mattos, J.R.A. (2003) Treatment of Strong Wastewater Using Advanced Oxidation Process (AOP) and Biological Process (BP) to Reduction of Chemical Oxygen Demand (COD) in Samples from Polyester Manufacturing Industry. Conferencia Científica Internacional Medio Ambiente Siglo XXI (MAS III), Santa Clara.

[15] Guimarães, O.L.C. and Silva, M.B. (2007) Hybrid Neural Model for Decoloration by $\mathrm{UV} / \mathrm{H}_{2} \mathrm{O}_{2}$ Involving Process Variables and Structural Parameters Characteristics to Azo Dyes. Chemical Engineering and Processing, 46, 45-51. 
http://dx.doi.org/10.1016/j.cep.2006.04.005

[16] Nogueira, R.F.P., Trovó, A.G., Silva, M.R.A., Villa, R.D. and Oliveira, M.C.O. (2007) Fundamentos e aplicações ambientais dos processos Fenton e foto-Fenton. Química Nova, 30, 400-408. http://dx.doi.org/10.1590/S0100-40422007000200030

[17] Freire, R.S., Pelegrini, R., Kubota, L.T. and Durán, N. (2000) Novas tendências para o tratamento de resíduos industriais contendo espécies organocloradas. Química Nova, 23, 504-511. http://dx.doi.org/10.1590/S0100-40422000000400013

[18] Guzzella, L., Feretti, D. and Monarca, S. (2002) Advanced Oxidation and Adsorption Technologies for Organic Micropollutant Removal from Lake Water Used as Drinking-Water Supply. Water Research, 36, 4307-4318. http://dx.doi.org/10.1016/S0043-1354(02)00145-8

[19] Peixoto, A.L.C. and Izário Filho, H.J. (2010) Statistical Evaluation of Mature Landfill Leachate Treatment by Homogeneous Catalytic Ozonation. Brazilian Journal of Chemical Engineering, 27, 531-534. http://dx.doi.org/10.1590/S0104-66322010000400004

[20] Peixoto, A.L.C., Silva, M.B. and Izário Filho, H.J. (2009) Leachate Treatment Process at a Municipal Stabilized Landfill by Catalytic Ozonation: An Exploratory Study from Taguchi Orthogonal Array. Brazilian Journal of Chemical Engineering, 26, 481-492. http://dx.doi.org/10.1590/S0104-66322009000300004

[21] Salazar, R.F.S. and Izário Filho, H.J. (2010) Aplicação de processo oxidativo avançado (POA) como pré-tratamento de efluente de laticínio para posterior tratamento biológico. Analytica (São Paulo), 45, 60-61.

[22] Samanamud, G.R.L., Lourea, C.C.A., Souza, A.L, Salazar, R.F.S., Oliveira, I.S., Silva, M.B. and Izário Filho, H.J. (2012) Heterogeneous Photocatalytic Degradation of Dairy Wastewater Using Immobilized ZnO. ISRN Chemical Engineering, 2012, Article ID: 275371. http://dx.doi.org/10.5402/2012/275371

[23] Fahami, Nishijima, W. and Okada, M. (2003) Improvement of DOC Removal by Multi-Stage AOP-Biological Treatment. Chemosphere, 50, 1043-1048. http://dx.doi.org/10.1016/S0045-6535(02)00617-3

[24] Barrado, E., Vega, M., Grande, P. and Del Valle, J.L. (1996) Optimization of a Purification Method for Metal-Containing Wastewater by Use of a Taguchi Experimental Design. Water Resource, 30, 2309-2314.

[25] Taguchi, G. and Konishi, S. (1987) Taguchi Methods Orthogonal Arrays and Linear Graphs: Tools for Quality Engineering. American Supplier Institute, Dearborn, Michigan.

[26] Lizama, C., Freer, J., Baeza, J. and Mansilla, H.D. (2002) Optimized Photodegradation of Reactive $\mathrm{Blue}_{19}$ on $\mathrm{TiO}_{2}$ and ZnO Suspensions. Catalysis Today, 76, 235-246. http://dx.doi.org/10.1016/S0920-5861(02)00222-5

[27] Rodríguez, M., Abderrazik, N.B., Contreras, S., Chamarro, E., Gimenez, J. and Esplugas, S. (2002) Iron(III) Photoxidation of Organic Compounds in Aqueous Solutions. Applied Catalysis B: Environmental, 37, 131-137. http://dx.doi.org/10.1016/S0926-3373(01)00333-2

[28] Silva, M.B. (1996) Estudo das Condições de Preparação, Caracterização e Reatividade de Catalisadores de Prata Suportada em Alumina. Tese de Doutorado, Faculdade de Engenharia Química/Universidade Estadual de CampinasUNICAMP. 
Scientific Research Publishing (SCIRP) is one of the largest Open Access journal publishers. It is currently publishing more than 200 open access, online, peer-reviewed journals covering a wide range of academic disciplines. SCIRP serves the worldwide academic communities and contributes to the progress and application of science with its publication.

Other selected journals from SCIRP are listed as below. Submit your manuscript to us via either submit@scirp.org or Online Submission Portal.
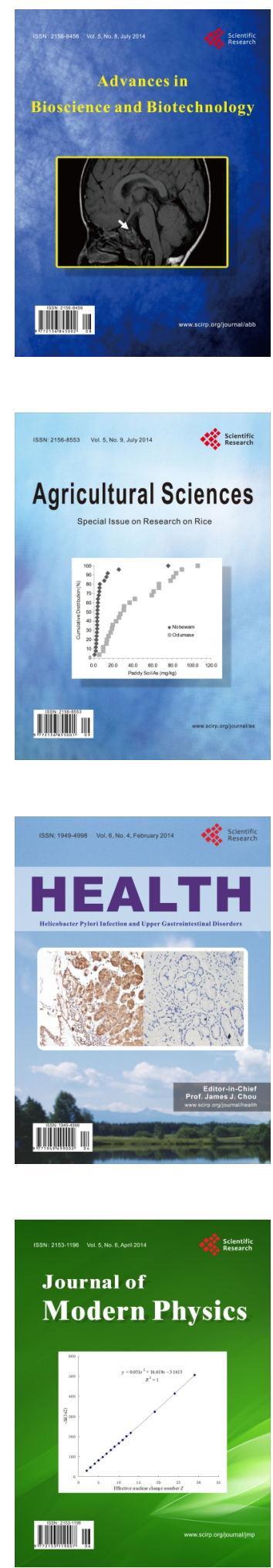
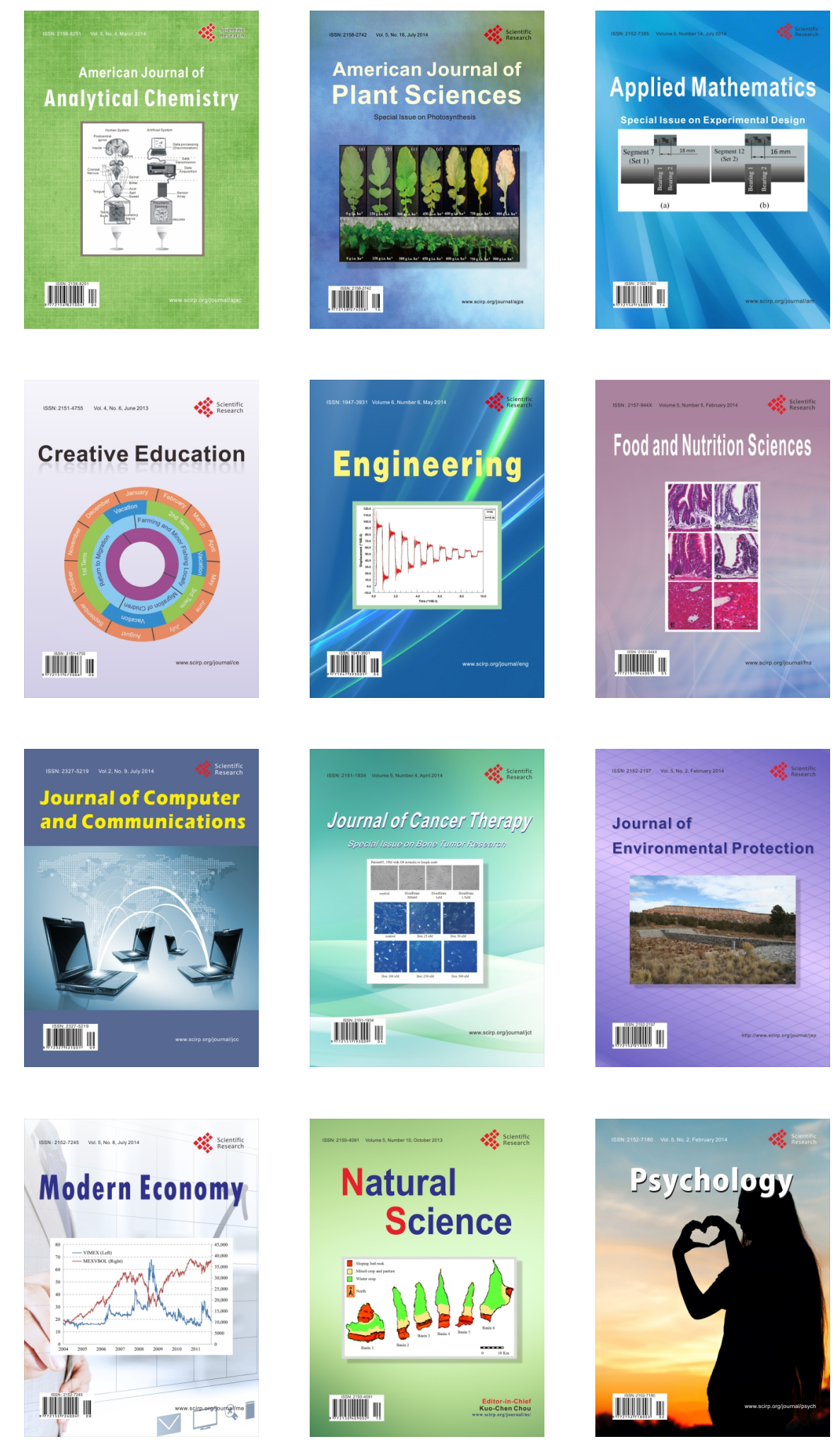